\title{
A MODERN PALEOLIT ÉTREND ÉS AZ ÚJ CSODANÖVÉNYE A FÖLDI MANDULA
}

\author{
Panyor Ágota - Rabb Mercédesz
}

\begin{abstract}
The healthy nutrition is essential for the subsistence of people. It is everyone because it is part of our daily routine and it is timeless. The main aim of our research was to represent the Palaeolithic lifestyle and to introduce the ground almond and to highlight the multiple use of this plant. In addition to this to find out if the domestic representatives of the Palaeolithic lifestyle heard about it and which form they use it.
\end{abstract}

Kulcsszavak: paleolit életmód, földi mandula, gumó, laktózmentes, gluténmentes

Keywords: Palaeolithic lifestyle, ground almonds, tubers, lactose-free, gluten-free

\section{Bevezetés}

A paleolit táplálkozás a kőkorszakban jött létre, amelynek lényege, hogy őseink a homo sapiens 2-2,5 millió évvel ezelőtt jelentek meg a Földön és vadászó - halászó - gyüjtögető életmódot folytattak, amelyekhez alkalmazkodott az emberi szervezet. Öseink egészségesek voltak, táplálkozásukban még nem volt jelen sem a tej, sem a gabona (Szendi, 2009).

Loren Cordain (2011) a Colorado Állami Egyetem professzora forradalmasította a paleolit táplálkozást az amerikai emberek életében a „Paleolit étrend” és a „Paleolit válasz" címü könyveiben. Ô vázolta fel az étrend legfontosabb alapelveit. Fontos szempont, hogy mellőzik a só, cukor, hüvelyesek, gabonamagvak és a tejtermékek fogyasztását.

A földi mandula termékei teljes mértékben beilleszthető ebbe az étrendbe. A növény Észak-Afrikából származik. A fáraók idején kezdték el termeszteni a Nílus mentén. Jelenleg Nyugat-Afrikában és Dél-Európában honos növény és legnagyobb területen Spanyolországban, Törökországban, USA-ban és az afrikai országokban termesztik.

Hazánkban több elnevezése is ismert a növénynek, mint a földi mandula, mandulafü, mandulapala, tigrisdió és a tigrismogyoró. 5 változata van a növénynek, amelyböl 4 gyomnövény és egy kultúrnövény. Kutatásunkban ezt az egy kultúrnövény változatát tanulmányoztuk.

A földi mandula a palkafélék családjába tartozik. Egy lágyszárú, gyöktörzses növény, amelyet egyéves növényként termesztenek. Szaporítása gumóival történik, melynek ültetési ideje március 28-tól április 15-ig tart, ilyenkor a talaj hőmérséklete eléri a $12^{\circ} \mathrm{C}$-ot, amely a csírázáshoz optimális. Sor- és tőtáv kialakitásánál a legpraktikusabb a 65-70 cm-es sor, és 6-8 cm-es tötávolság, mert július közepére egy „fücsomó" növekszik belöle melynek lombozata 73-75 cm magasságot is elérhet (1. ábra). Egy elültetett gumóból átlagosan $100 \mathrm{db}$ gumócska fejlödik ki, a gumók 0,5-1,5 cm nagyságúak (2. ábra). Betakarítása október második felében történik. 


\section{1. ábra: Földi mandula lombozata}

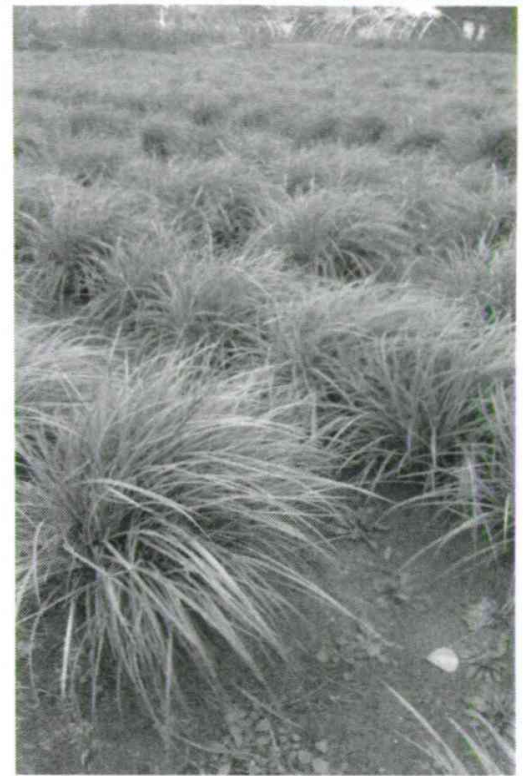

Forrás: A szerzök felvétele (2016)

\section{2. ábra: Földi mandula gumó}

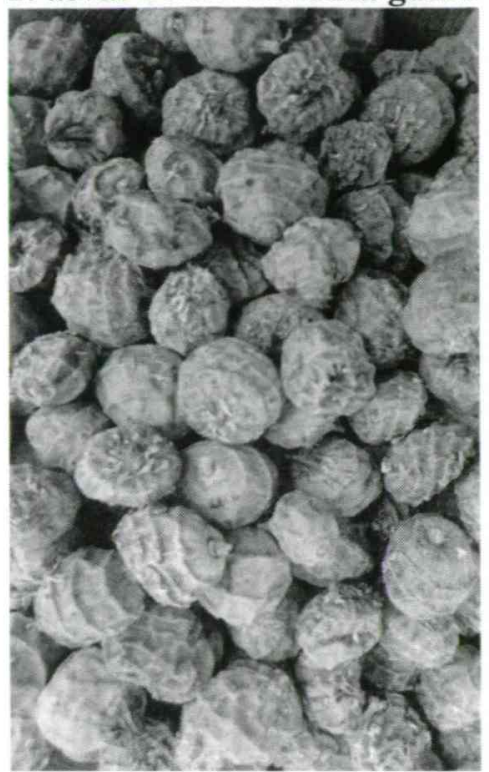

Forrás: A szerzők felvétele (2016)

Termesztése igen gazdaságos, mert hektáronkénti vetőgumó szükséglete 100$120 \mathrm{~kg}$ és a betakarítást követően átlagosan 18-20 t/ha gumó takarítható be.

Felhasználása igen sokoldalú. Fő felhasználási területe az élelmiszeripar, mint földi mandulaliszt, -tej, -olaj, -panír, és -őrlemény. Használható kertekbe, udvarokba, parkokba, mint dísznövény. Alapanyagát képezi kozmetikumoknak és gyógyszereknek. Humán táplálkozásra hazánkban még alig elterjedt, ezért is kívánjuk munkánkban részletesebben feltárni azokat a lehetőségeket, amely a fogyasztás növekedését fokozhatja.

Humán fogyasztásra előállítható élelmiszerek:

a) Földi mandulatej: A gumókból készített „,tej” kiváló helyettesítő terméke a tehén, illetve kecsketejnek. Ez azért is lényeges, mert nem tartalmaz laktózt, hormonokat, tejfehérjéket, magas a kalcium tartalma és kedvező az enzim összetétele. Azonnal fogyasztva vagy ultrapasztőrözött (UHT) formában fogyasztható (3. ábra). A földi mandula gumójából készítik Spanyolországban a „La Horchata de Chufa de Valencia” nevủ ,chufa-tejet”. Valencia tartományban „oltalom alatt álló földrajzi jelzés” eredetmegjelölést kapott. 


\section{3. ábra: UHT földi mandulatej}

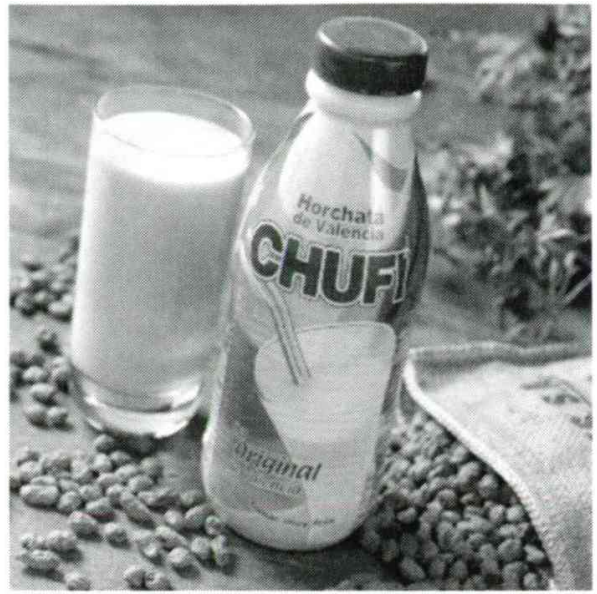

Forrás: https://hu.pinterest.com/pin/396316835938622283/ (2016)

b) Földi mandula liszt: Legfontosabb tulajdonsága, hogy gluténmentes és nagyon kedvező a rosttartalma (4. ábra). Ez abban is megmutatkozik, hogy a sima mandula liszt rosttartalmához képest 4-6-szor magasabb a rosttartalma. Ennek köszönhetö, hogy alacsony a glikémiás indexe. Az aminosav összetétele is kedvezőbb a sima mandula liszthez képest.

\section{4. ábra: Földi mandula liszt}

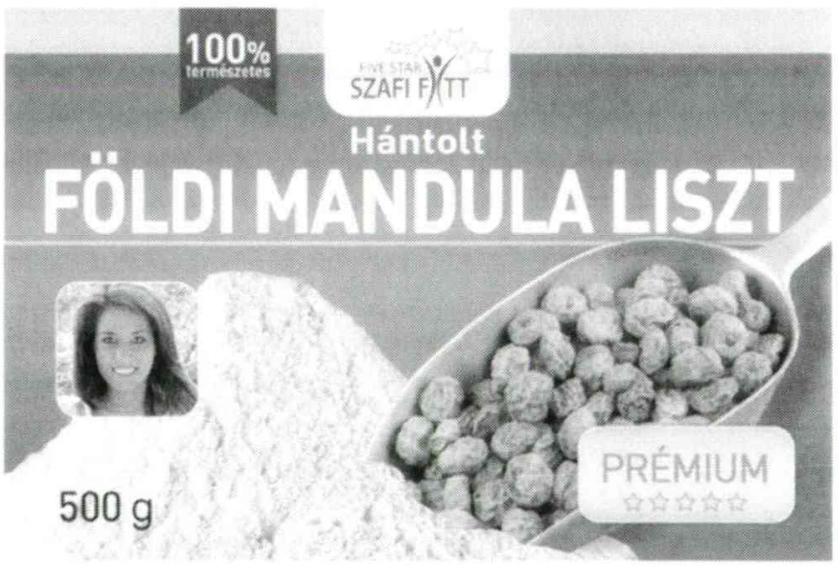

Forrás: http://www.szer-etet.hu/szafi_fitt_foldimandula_liszt_500_gr_620 (2016)

c) Földi mandula panír: A hántolt földi mandulából készített örlemény kiváló alternatívája a hagyományos zsemlemorzsának. Kiválóan alkalmazható bundázott ételek panírozásához, elkészítéséhez. A földi mandula liszthez hasonlóan élelmi rostokban gazdag, gluténmentes termék (5. ábra). 


\section{5. ábra: Földi mandula panír}

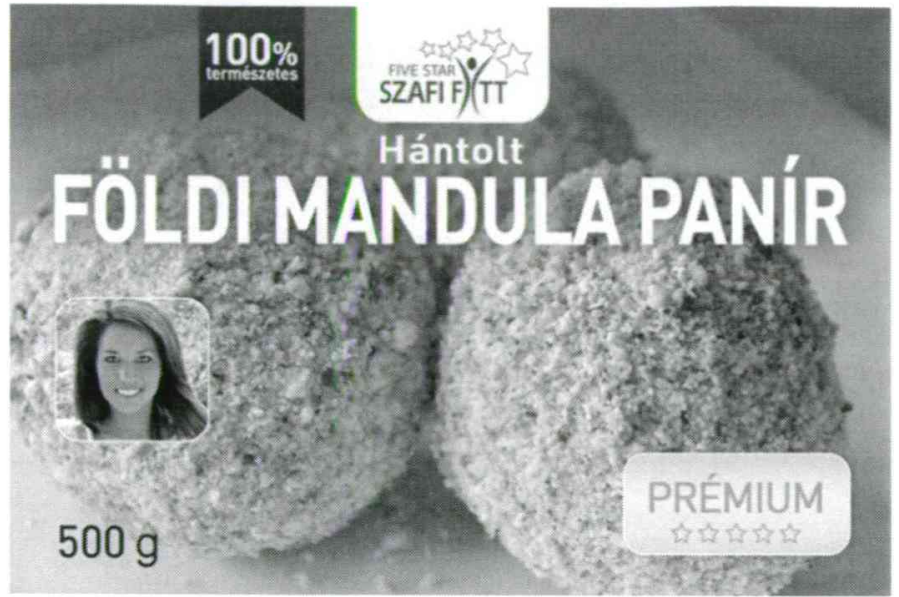

Forrás: http://www.szafi-fitt.hu/product/szalfi-fitt-premium-hantolt-foldi-mandula -panir-500g/ (2016)

d) Földi mandula olaj: Hidegen sajtolt, sötétarany színű, amelynek édeskés, enyhe dió aromájú az illata. Egyenértékủ az extra szüz olívaolajjal. Zsírsav összetétele kiváló, hiszen telített zsírsav tartalma igen alacsony (14-16\%), telítettlen zsírsav tartalma viszont magas. A létfontosságú zsírsav tartalma is igen kedvezőek, mert Omega-6 zsírsavtartalma 12\%, míg Omega-9 zsírsavtartalma 72\%. Fözésre és saláták elkészítéséhez kiváló (6. ábra).

\section{6. ábra: Földi mandula olaj}

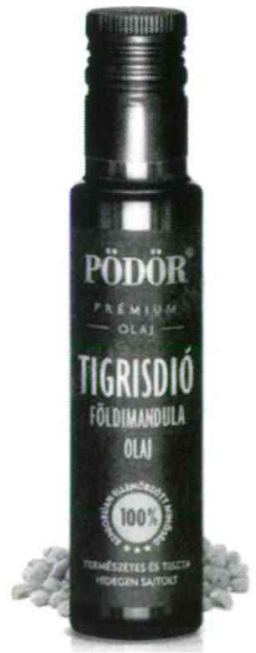

Forrás: http://www.podor.hu/foldi-mandula---tigrisdio-olaj (2016) 


\section{Anyag és módszer}

Primer kutatásunk keretében - kérdőíves megkérdezés segítségével - felmérést készítettünk paleolit életmódot folytató személyekkel. Összesen 132 fö vett részt a kérdőív kitöltésében, melyben 119 nő és 14 férfi volt. A kérdések a paleo életmódra, a földimandula növényre, illetve termékeinek ismertségére vonatkoztak.

\section{Kutatási eredmények}

A kérdőív első részében a paleolit életmóddal kapcsolatos kérdéseket tettünk fel. Elsőként arra kerestük a választ, hogy vajon miért kezdték el alkalmazni az életmódot, ezért kombinatív kérdést tettünk fel, amelyben több lehetőséget is bejelölhettek. Ebből megtudhattuk, hogy legtöbben az egészséges életmód és a fogyókúra miatt kezdték el alkalmazni az életmódot.

Érdeklődtünk, hogy az életmód alkalmazását követően vettek-e észre valamilyen változást. A 132 főből 120-an vettek észre változást és egy nyitott kérdésben megkértük őket, hogy osszák meg velünk tapasztalataikat. A legtöbb választ a 7 . ábrán összegeztuik, amely alapján elmondhatjuk, hogy a kitöltők egyöntetűen egyetértettek abban, hogy jobb lett a közérzetük, több energiával rendelkeztek és veszítettek a testsúlyukból.

\section{7. ábra: A megkérdezettek észrevételei az életmód alkalmazása óta (fó, $\mathbf{n = 1 2 0}$ )}

Izületi problémák enyhülése, megszünése

Jobb alvás

Allergia enyhülése, megszünése

Vérnyomás stabilizálása

Nincs kívánóság, éhségérzet

Jobb közérzet

Pajzsmirigy funkciók javulása

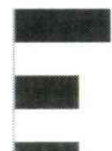

Energikusabb

Szebb bör, haj és köröm

Emésztés javulása

Fogyás

Cukorbetegség javulása
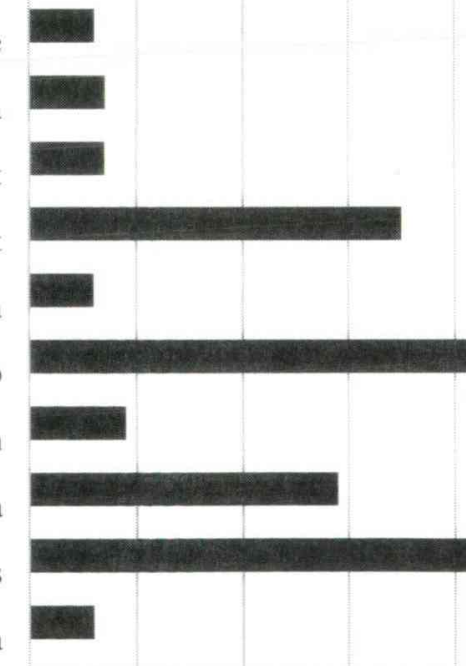

0

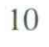

20

30

40

50

60

Forrás: Primer kutatás alapján saját szerkesztés 
A résztvevők közül 79 fő már hallott a növényről, viszont a földimandula termékeiről már csak 64 fő hallott. Arról is érdeklődtünk, hogy akik nem ismerik a termékeket, megismerkednének-e vele és a 68 főből 61 szívesen megismerkedne a termékekkel és 7 fỏ zárkózik el az új információktól.

Akik hajlandóságot mutattak, az internet, virtuális háló segítségével ismerkednének meg a termékekkel, amin nem lepődtünk meg, hiszen napi szinten használjuk és a leggyorsabb módon kerülhetünk az új információk birtokába. Ezen kívül fontosnak tartják a bolti eladók ajánlását, hisz bizalommal vannak irántuk, valamint magazinokban és könyvekben is szívesen megismerkednének a termékekkel.

A kérdőív további részében azoknak tettük fel kérdéseinket, akik már fogyasztottak földi mandula termékeket. Elsőként aziránt érdeklődtünk, hogy a növény termékei közül melyeket használták. Számunkra nem meglepő módon az 53 főből 47 személy használta már a lisztet, a panírt 22 fó és a mandulatejet 14 fö. A mandula olajat csupán egy fő (8. ábra).

\section{8. ábra: A földi mandulából előállított termékek használatának formái (fö, $\mathrm{n}=\mathbf{5 4}$ )}

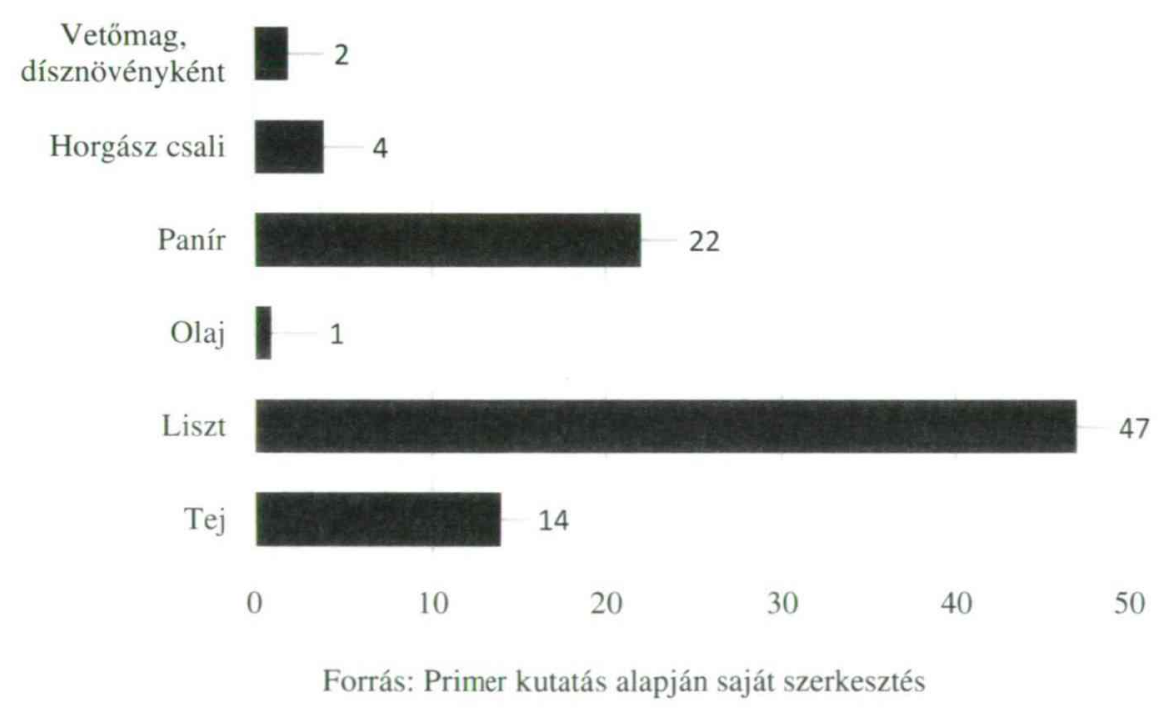

Fontosnak tartottuk, hogy említést tegyünk a termékek jellemzőiröl, így az íz, állag, eltarthatóság, ár és a beszerezhetőség. Szemantikus-skála segítségével 1-től 5ig minősíthették a szempontokat, amelyben az 5-ös jelentette a legjobb értékelést. Mivel a lisztet próbálták ki legtöbben, ezért ennek az értékelését szemléltetjük a 9. ábrán. Látható, hogy a liszt ízével, illatával és állagával teljesen meg voltak elégedve. Viszont az árával és beszerezhetőségével már kevésbé, hiszen ezeket már 
csak jellemzően közepesre értékelték, Meglehetősen nehéz a termékek beszerezhetősége, mivel kevés helyen forgalmazzák.

\section{9. ábra: Földi mandula liszt értékelése (n=47)}

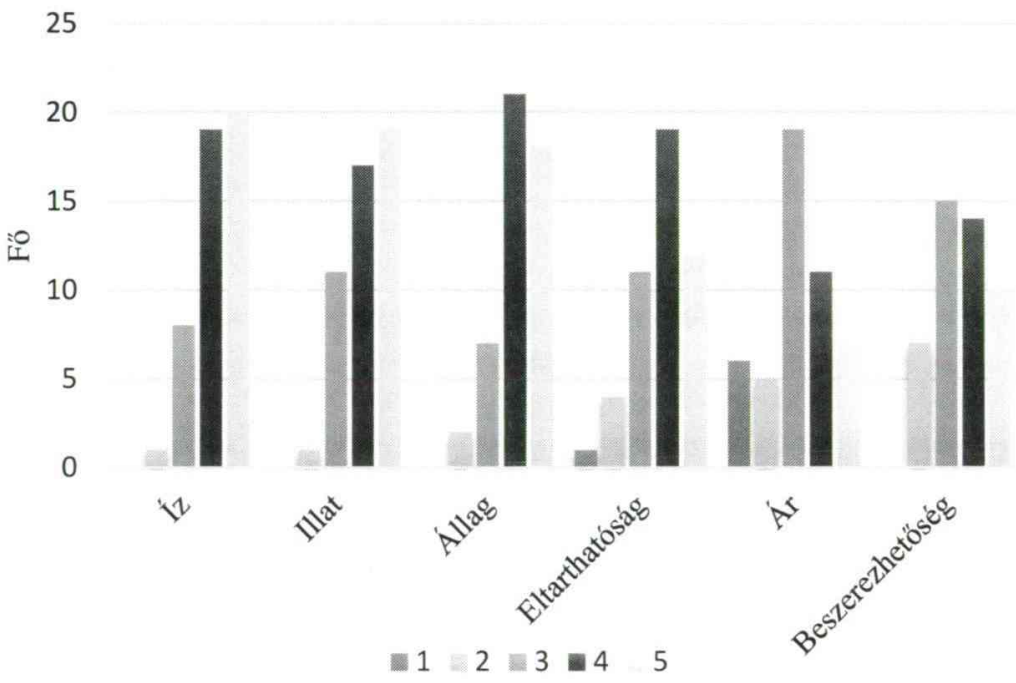

Forrás: Primer kutatás alapján saját szerkesztés

Végezetül felmértük, hogy a földi mandulából készült élelmiszereket kipróbálnák-e, amelyeket még nem használtak, milyen lenne a fogyasztási hajlandóságuk. Az 53 főből 44 fő szívesen kipróbálná a további termékeket. Mint korábban megtudtuk, legtöbben a lisztet már használták és a 10. ábrán látható, hogy a tejet, olajat, panírt is szívesen kipróbálnák, valamint, aki még nem használta a lisztet, azok mind kipróbálnák. 


\section{0. ábra: A földi mandulát használók további termékek iránti kereslete (n=44)}

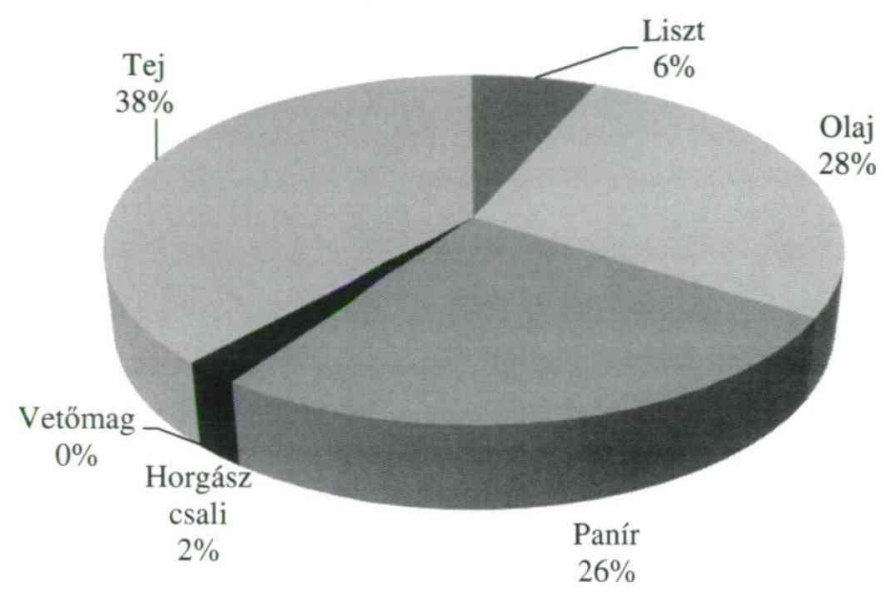

Forrás: Primer kutatás alapján saját szerkesztés

\section{Következtetések, összefoglalás}

A kérdőíves kutatásunk során egyértelmüen bizonyítást nyert, hogy az emberek az egészséges életmód és a testsúlycsökkentés miatt választják a paleolit életmódot. Akik paleolit életmódot folytatnak, egyöntetűen megszabadultak súlyfeleslegeiktől, több energiával rendelkeznek és jobb lett a közérzetűek, valamint vérnyomás és ízületi panaszaik enyhültek. A kutatásunkból kiderült, hogy többen ismerték a földi mandula növényt, mint ahogyan azt mi gondoltuk. Viszont a földi mandula termékekről már csak a kutatásban résztvevők fele halott. Többségük az internetről szerezne tudomást a növényről, hiszen hazánkban annyira új a földi mandula és termékei, hogy máshonnan nem is nagyon tudnának információhoz jutni. Hazánkban úgymond még ,gyerekcipőben jár” az ismertsége és a fogyasztása.

Akik még nem ismerték a földi mandula termékeit szívesen megismernék az internet, bolti eladók és újságok, magazinok ismeretterjesztő információi alapján. A termékek közül a földi mandula liszt és a panír a legelterjedtebb. Ezen az eredményen nem lepődtünk meg, mert gyakorlatilag a boltokban és a web shopokban szinte csak ezt a két terméket lehet beszerezni.

Azok a fogyasztók (kutatásunk résztvevői), akik eddig kipróbáltak a földi mandula termékeket, teljes mértékben elégedettek voltak a minőségével, állagával, ízével. A megkérdezettek további érdeklődést mutattak a panír, illetve az olaj iránt, szívesen kipróbálnák. Meglátásunk szerint az emberek nyitottak az új termékek és felhasználásuk alternatívái iránt. Véleményünk szerint lehetne növelni és fokozni a földi mandula termékeinek az ismertségét, mind fogyasztói, mind értékesítési oldalról. A termékeket a paleolit életmódon, táplálkozáson keresztül mutattuk be, mert paleolit termékként kerülnek forgalmazásra az üzletekben. Ugyanakkor beltartalmi értékei alapján a termékek kiválóan alkalmasak az élelmiszer allergiások számára, továbbá a vegetáriánusok, cukorbetegek és az egészséges életmódot követők számára is. 
A piaci szegmensek tekintetében fontos elérni azokat a személyeket, akik funkcionális élelmiszerként tudnák a földi mandula termékeit használni. Ezen speciális termékek azon piaci rés számára kedvezőek, akik például tejcukor- vagy gluténérzékenyek. Ők olyan kisméretü szegmentumok, akiknek egyedi, speciális igényeik vannak. Szórólapokkal, prospektusokkal kellene a figyelmüket felhívni arra, hogy ezen termékek kiváló alternatívák a problémáikra.

Szakácsok, paleolit szakácskönyv írók használhatnák a termékeket, mint főzési alapanyagokat. Ök felkelthetnék a fogyasztók figyelmét ezen új és egészséges termékek iránt, hogy ösztönözzék öket a megvásárlására és kipróbálására. A földimandula termékek népszerüsítésére alkalmasak lehetnek az élelmiszer kiállítások, termékbemutatók, mivel a fogyasztók közvetlen módon kipróbálhatják a termékeket. Továbbá női magazinokban, speciális kiadványokban szintén fontos lenne publikációk, szakcikkek megjelenítése a növényröl és termékeiröl, annak egészséges, jótékony hatásairól és felhasználásának sokoldalúságáról.

\section{Felhasznált irodalom}

Gibbons A. (2014): Paleo étrend régen és ma. National Geographic Magyarország. 2014. 12./9. 84107.

Loren C. (2011): Paleolit étrend. Jaffa Kiadó, Budapest

Loren C. (2012): Paleolit válasz. Jaffa Kiadó, Budapest

Melegh S. (2015): A paleolit étrendről röviden 1. rész. Új diéta 24./1. 30-32.

Melegh S. (2015): A paleolit étrendröl röviden 2. rész. Új diéta 24./2-3. 35-36.

Posta R. (2012): Paleolit fogyókúra hedonistáknak. Jaffa Kiadó, Budapest

Szendi G. (2009): Paleolit táplálkozás. Jaffa Kiadó, Budapest

Tóth Cs. (2012): Paleolit orvoslás. Jaffa Kiadó, Budapest

https://www.agronaplo.hu/szakfolyoirat/2008/05/szantofold/a-mandulafu_(2016.04.10.)

http://valeyracexotics.tumblr.com/post/73610520675/4-a-f\%C3\%B6ldimandula_(2016.04.16) 